\title{
DIE GEBRUIK EN DOELTREFFENDHEID VAN ORGANISASIEONTWIKKELINGSTEGNIEKE IN 73 GROOT SUID-AFRIKAANSE ORGANISASIES
}

\author{
L.D. COETSEE \\ E.A. COSTER \\ A.M. VAN NIEKERK \\ DEPARTEMENT BEDRYFSIELKUNDE \\ UNIVERSITEIT VAN SUID-AFRIKA
}

\begin{abstract}
Data on various aspects regarding the use of Organisational Development techniques (OD-techniques) in 73 large South African organisations indicate that OD-practice is founded on a sound scientific basis in some of these organisations. In other organisations the use of OD-techniques are characterised by the problems typically found in many organisations overseas. The specific problems and their possible causes are discussed and some proposals for the improvement of OD-practice are made.
\end{abstract}

Gedragswetenskaplike kennis het gedurende die afgelope drie dekades vinnig toegeneem. Een van die sub-terreine van die gedragswetenskappe waarop veral aktief gewerk is, is dié van organisasie-ontwikkeling (OO) wat in die algemeen beskryf word as die toepassing van gedragwetenskaplike kennis in organisasies ten einde sekere veranderinge in organisasies te weeg te bring. Die toepassing van OO-tegnieke het die maksimering van individuele doeltreffenheid en bevrediging, en van organisasie-effektiwiteit, ten doel. Daar bestaan egter heelwat probleme in verband met die toepassing van OO-tegnieke. Die doeltreffendheid en uitwerking van die tegnieke is veral onder verdenking terwyl daar heelwat leemtes inherent aan en in die toepassing van die tegnieke blyk te wees. Hierdie probleme word in die artikel toegelig nadat die konsep organisasie-ontwikkeling gedefinieer is. Die resultate van 'n ondersoek na die gebruik van OO-tegnieke in van die grootste organisasies in Suid-Afrika word teen bogenoemde agtergrond weergegee en bespreek. 


\section{DIE BEGRIP ORGANISASIE-ONTWIKKELING $(O O)$}

Een van die bekendste en steeds mees populêre definisies van OO is die van Beckhard (1969, p.9): "Organization development is an effort (1) planned, (2) organization wide, and (3) managed from the top, to (4) increase organization effectiveness and health through (5) planned interventions in the organization's 'processes', using behavioural science knowledge".

Ons sien $\mathrm{OO}$ as 'n 'op-behoefte-gebaseerde (soos deur diagnose aangetoon) beplande, sistematiese proses van langtepmyn veranderinge, gegrond op gedragwetenskaplike teorieë en waarby alle organisasie substelsels betrek word, ter verbetering van organisasiedoeltreffendheid en die doeltreffendheid en bevrediging van organisasielede'.

In die literatuur word daar soms 'n onderskeid getref tussen bestuurderontwikkeling en organisasie-ontwikkeling. Volgens Beckhard (1969, p.20) is die verskil geleë in wie die kliënt is. Die doel van bestuurderontwikkeling is om die vaardighede, vermoëns en kapasiteite van die bestuurders (die kliënt) te verbeter. By organisasie-ontwikkeling is die doel die verbetering van alle substelsels van die organisasie (die kliënt). OO kan dus gesien word as die meer omvattende begrip wat ook bestuurderontwikkeling insluit. Vir die doeleindes van die artikel sal OO dan ook so beskou word.

\section{Die doeltreffendheid van OO-tegnieke}

Dit is bekend dat heelwat geld en man-ure aan die toepassing van OO-tegnieke bestee word. Navorsing dui egter daarop (Beer, 1976; Bowers, 1976; Kahn, 1974; Levinson, 1972; Tichy 1974) dat alhoewel OO-tegnieke reeds vir drie dekades in die Verenigde State van Amerika toegepas word, daar min wetenskaplike bewyse bestaan dat dit gelei het tot die verhoging van individuele en organisasie-doeltreffendheid. Trouens, die kenners, waarna hierba verwys is, is dit eens dat die gevolge en uitwerking van die toepassing van OOtegnieke het, in 'n groot mate nog bekend is. Dit kan, volgens sommige van hulle, veral daaraan toegeskryf ward dat die resultate van OO-pogings nie dikwels openbaar gemaak word nie.

Dit blyk dat OO-praktisyns in die algemeen 'n groot weerstand openbaar teen die evaluering van hul ingrypings in organisasies. Tichy (1974) en Brown en Somerville (1977) sê dat in baie min organisasies pogings aangewend word om te bepaal of die gebruik van OOtegnieke gesonde beleggings is in terme van geld en man-ure bestee. Daar bestaan, na ons wete, geen gepubliseerde studies na die doeltreffendheid van OO-tegnieke wat in Suid-Afrika 
toegepas is nie. Een van die min omvattende ondersoeke na die doeltreffendheid van OOtegnieke tot op datum is die van Bowers (1973) waar 14000 respondente, afkomstig uit 23 organisasies in die Verenigde State van Amerika, by betrek is. Verskillende doeltreffendheidmetings, voor en na elke afsonderlike toepassing van OO-tegnieke, is vergelyk. Die resultate van die studie dui daarop dat die toepassing van

- $\quad$ opname-terugvoertegnieke ("survey feedback techniques") gelei het tot statisties beduidende verbeteringe ten opsigte van die oorgrote meerderheid metings

- $\quad$ interpersoonlike-proseskonsultasietegnieke ook ten opsigte van die meerderheid metings ' $n$ verbetering (alhoewel nie in al die gevalle statisties beduidend nie) getoon het

- $\quad$ taakproseskonsultsietegnieke geen veranderinge in metings teweeggebring het nie

- laboratoriumopleidingstegnieke, en waar geen opleiding gegee is nie, beide tot afnames in doeltreffendheidsmetings gelei het.

Die bevindings versterk die vermoede wat reeds deur ander skrywers soos Levinson (1972), Bass (1967), Deep, Bass en Vaughan (1967) geopper is, naamlik dat laboratoriumopleiding teenproduktief kan wees, met ander woorde, naegatiewe en selfs destruktiewe gevolge mag hê, soos byvoorbeeld 'n afname in doeltreffendheid. Dit blyk dus dat die toepassing van OO-tegnieke in die algemeen en veral laboratoriumtegnieke, dusver telerustellende resultate gelewer het. Die rede hiervoor word veral toegeskryf aan sekere tekortkominge in die tegnieke self en in die toepassing daarvan.

\section{Die belangrikste tekortkominge van OO-tegnieke}

\section{Gebrekkige teoretiese grondslag}

Ons het OO omskryf as gegrond op wetenskaplike beginsels en dat dit gebruik maak van gedragwetenskaplike kennis. Verskeie skrywers (onder andere Bowers, 1976; Kahn, 1974; Levinson 1972) is dit eens dat een van die belangrikste tekortkominge van baie OOtegnieke daarin geleë is dat dit nie aan wetenskaplike vereistes voldoen nie. Kontemporêre organisasieteorieë het nog nie iets wesenliks bygedra tot die gebied van organisasieontwikkeling nie (Friedlander en Brown, 1975; Levinson 1972) en gevolglik kan OO nie aanspraak maak op 'n wetenskaplike teoretiese onderbou nie. In veral laboratorium-opleiding word daar dikwels van clichés gebruik gemaak soos 9,9 of selfaktualisering-terme wat nog nie genoegsaam verfyn is ten einde psigologiese intervensie op grond daarvan moontlik te maak 
nie. Levinson (1972) beweer dat meeste OO-tegnieke 'n foefie ("gimmick") is en Kahn (1974) wys daarop dat die term Grid Organization Development geregistreer is as 'n handelsmerk of produk

- $\quad$ die antitese van wetenskaplike konseptualisering.

\section{Indikasie ontleding (diagnose) word nie deurgaans gebruik nie}

In Beckhard se definisie van OO word daarop gewys dat dit 'n beplande proses is en in die verdere omskrywing word pertinent aangetoon dat dit 'n "op-behoefte-gebaseerde (soos deur diagnose aangetoon)" proses is. Die kritiek dat die werk van baie OO-konsultante gekenmerk word deur tegniek gebondenheid is al dikwels gehoor. Dieselfde tegnieke word in elke organisasie of afdeling van organisasies toegepas, ongeag die unieke probleme van die spesifieke organisasie of afdeling. Daar word dus in sulke gevalle aanvaar dat dieselfde OOtegnieke van toepassing is en suksesvol sal wees vir alle betrokke individue en organisasies.

Sistematiese en beplande verbetering van 'n organisasie vereis volgens kenners (Beckhard, 1969; Levinson, 1972; Huse, 1975; Beer, 1976) in die eerste plek 'n deeglike diagnose van die verskillende substelsels van die organisasie, en van prosesse (byvoorbeeld besluitneming en kommunikasie). Die indikasie ontleding behoort die basis te vorm vir die beplanning van die organisasie-ontwikkelingsprogram, insluitende die keuse van die spesifieke OO-tegnieke wat toegepas gaan word.

Navorsing (Bowers, 1976) dui daarop dat OO-konsultante in die algemeen en veral diegene wat aan laboratoriumopleidingstegnieke voorkeur gee, óf 'n deeglike indikasie ontleding versaak óf waar daar wel so 'n ontleding gemaak word, die gegewens dikwels nie reg benut nie.

Alle organisasie substelsels word nie deurgaans betrek nie

Beckhard (1969) beklemtoon in sy definisie dat OO 'n "organization wide" benadering moet wees. In die verdere omskrywing word dit gemeld dat "alle organisasie substelsels betrek (moet) word".

Die toepassing van sekere OO-tegnieke is gemik op die verandering van ' $n$ spesifieke substelsel van die organisasie. Voorbeelde hiervan is laboratoriumtegnieke wat gebruik word om die individuele of sosiale substelsels te verander, en doelwitbestuursopleiding gerig is op die verandering van die bestuurstelsel. Die interafhanklikheid en interaksie van alle substelsels in 'n organisasie en hul dinamika word vandag wyd in die literatuur erken. Die 
besondere prominensie wat die stelselbenadering in die literatuur oor organisasiegedrag geniet, dien as 'n bewys hiervan. Dit wil voorkom asof die stelselbenadering in OO-praktyke in 'n groot mate oor die hoof gesien word en in sulke gevalle word dit dus nie in ag geneem nie dat 'n verandering, in 'n enkele substelsel van die organisasie, onvoorsiene gevolge vir die ander substelsels en die organisasie as gehee1 mag inhou.

\section{Daar word nie deurgaans rekening gehou met die "oordrag van leer"-probleem nie}

Daar bestaan baie min bewyse dat gedragsvorme wat deur middel van OO-tegnieke aangeleer word wel na die werksituasie oorgedra word. In dié verband merk Argyris (1971) op dat alhoewel laboratoriumtegnieke soos T-groepe nuwe gedragsvorme motiveer, dit min vaardighede verskaf wat in die werksituasie gebruik kan word. Gedurende 1aboratoriumopleiding word gedragsvorme soos "openheid" en "vertroue" - daar is a1 hierna verwys as die hoekstene van OO (Frank, 1976, p.2) - en "risiko neming" aangeleer. Na die opleiding keer individue terug na dieselfde werkrolle en rolverwagtings as voor opleiding. Individue ondervind dan dat daar 'n sterk konflik bestaan tussen die nuut aangeleerde gedrag en die norme, waardes en houdings van hul werkomgewing en kry hulle min geleentheid om wat hulle geleer het toe te pas.

\section{Kommersialisme en gebrekkige opleiding van konsultante}

Van die belangrikste oorsake van die swak resultate wat dusver met OO-tegnieke behaal is, mag volgens Bowers (1976), aan kommersialisme toegeskryf word. In advertensies waar OO-programme bekend gestel word, in veral semi-vakkundige tydskrifte en brosjures, word dikwels ongegronde aansprake gemaak ten opsigte van die verbetering van individuele en organisasiedoeltreffendheid deur midde1 van hierdie programme.

'n Verdere probleem behels die opleiding van konsultante. Levinson (1972) beweer dat meeste mense wat OO-tegnieke toepas nie oor genoegsame opleiding vir die taak beskik nie.

\section{Die doeltreffendheid van OO-tegnieke word selde geëvalueer teen eksterne (die sogenaamde "harde") kriteriadata}

Dit is natuurlik dikwels nie prakties moontlik om in evalueringstudies gebruik te maak van eksterne kriteria nie. Waar evaluering wel onderneem word, word dikwels aan "sagte" kriteriumdata, veral houdingsveranderinge, voorkeur gegee. Daar kan heelwat besware teen die gebruik hiervan geopper word, byvoorbeeld dat dit subjektiewe kriteria is en in die geval 
van houdingsveranderinge bestaan daar min, indien enige, bewyse dat die houdingsveranderinge nie maar net kortstondig van aard is nie.

Uit die voorafgaande blyk dit dat alhoewe1 OO-tegnieke reeds vir ongeveer dertig jaar toegepas word, daar heelwat probleme bestaan op grond waarvan die doeltreffendheid van OO-tegnieke bevraagteken kan word.

Teen die agtergrond van die groot verskeidenheid probleme rondom die gebruik van OO-tegnieke is die algemene doel van hierdie ondersoek om vas te stel in watter mate die grootste organisasies in Suid-Afrika van OO-tegnieke gebruik maak, hoe hierdie tegnieke geïmplementeer word en of OO-praktyk in SuidAfrika ook die leemtes openbaar van OOpraktyk elders.

Die meer spesifieke doelstellings (aan die hand waarvan die resultate van die ondersoek ook weergegee en bespreek sal word) is om die volgende faktore rakende die gebruik van OO-tegnieke in die grootste Suid-Afrikaanse organisasies te ondersoek.

- Watter OO-tegnieke gebruik word.

- $\quad$ Die samestelling van OO-programme.

- Wie die gebruik van OO-tegnieke beplan en beheer.

- Of indikasie ontleding (diagnose) van opleidingsbehoeftes vooraf gemaak word en, indien wel, hoe hierdie diagnose gemaak word.

- $\quad$ Of die doeltreffendheid van OO-programme, na die afloop daarvan, geëvalueer word en, indien wel, hoe hierdie evaluering onderneem word.

- $\quad$ Hoeveel geld en man-ure gedurende die afgelope twee jaar aan OO-programme bestee is.

- $\quad$ Die mate waartoe OO-programme as doeltreffend beskou word.

\section{METODE}

Die gegewens is met behulp van 'n vraelys, wat spesifiek vir die doel van die ondersoek opgestel is, ingesamel.

Die vraelys is in beide ampstale opgestel en in boekvorm gebind. Dit, tesame met 'n begeleidende brief waarin die doel van die ondersoek en instruksies vir die voltooiing van die vraelys uiteengesit is en 'n gefrankeerde koevert, is aan die hoof van personeel en/of hoof van personeelopleiding van 280 organisasies gestuur. 
In die begeleidende brief is die versekering gegee dat geen name van individue of organisasies in navorsingsverslae vermeld sal word nie. 'n Afskrif van die uiteindelike navorsingsverslag is ook aan elke deelnemende organisasie belowe.

$\mathrm{Na}$ ontvangs van die voltooide vraelyste is die gegewens met behulp van 'n rekenaar verwerk.

\section{Monster}

Daar is besluit om slegs die grootste organisasies in SuidAfrika by die ondersoek te betrek.Dit is gedoen omdat daar van die veronderstelling uitgegaan is dat OO-tegnieke meer algemeen in gebruik sal wees by die organisasies as by klein organisasies.

Die name van die grootste organisasies is uit twee bronne verkry. Eerstens uit 'n verslag gepubliseer deur die Financial Mail Special Survey, getitel Top Companies, 22 April 1977. Vraelyste is gestuur aan die 50 organisasies gelys onder die opskrif The S.A. Giants League (p.66) wat volgens die opname beskou word as die grootste op grond van totale bates. 'n Verdere 80 vraelyste is gestuur aan organisasies wat in bogenoemde publikasie se lys The Top 100 (pp.19-25) opgeneem is en wat nie in eersgenoemde lys verskyn nie. Die organisasies is die grootste organisasies in Suid-Afrika op grond van hul totale bates, aandele markkapitaal en netto wins.

Die monster is aangevul uit 'n tweede bron, naamlik deur vraelyste te stuur aan die 150 grootste vervaardigingsorganisasies in Suid-Afrika (in terme van aantal werknemers in diens) wat nie reeds in die Financial Mail Special Survey se lyste opgeneem is nie. Die naamlys van organisasies is verkry van die Universiteit van Suid-Afrika se Buro vir Marknavorsing wat onder meer gemoeid is met die samestelling van sulke lyste.

Van die 280 uitgestuurde vraelyste is $119(42,5 \%)$ terug ontvang wat 65 van die 130 $(50 \%)$ vraelyste van die organisasies genoem in die Financial Mail Special Survey en 54 van die 150 (36\%) van die Buro vir Marknavorsing se lys insluit.

OO-tegnieke word nie in al die organisasies wat die vraelys voltooi het gebruik nie. Van die 119 organisasies pas 73 een of meer OO-tegnieke toe, terwyl 46 nie OO-tegnieke voor of ten tyde van die opname toegepas het nie. Die 73 organisasies wat wel OO-tegnieke gebruik, het gesamentlik meer as 625500 Blanke werknemers in diens.

Die monster sluit 'n verskeidenheid organisasies in soos bankinstellings, versekeringsorganisasies, vervoerorganisasies, ligte- en swaar nywerhede, mynbouinstellings en 
konstruksiemaatskappye. Daar is enkele semi-staatsondernemings in die monster, maar nie staatsdepartemente of departemente van provinsiale administrasies nie. Daar kan dus nie daarop aanspraak gemaak word dat hierdie monster verteenwoordigend is van groot SuidAfrikaanse ondernemings nie. Die resultate en die bespreking van die bevindings het dus slegs betrekking op die 73 organisasies, wat volgens die ondersoek, OO-tegnieke gebruik.

Uit 'n ontleding van gegewens wat die voltooiers van die vraelyste moes verstrek, blyk dit dat die persone in die algemeen hoëvlak poste in hul organisasies beklee en oor heelwat relevante ervaring met personeelwerk en personeelopleiding beskik om die gevraagde inligting vir die ondersoek te verstrek.

\section{RESULTATE EN BESPREKING}

\section{Die gebruik van OO-tegnieke}

'n Uiteensetting (in populariteitsvolgorde) van die OO-tegnieke wat in die 73 organisasies gebruik word, word in Tabel 1 weergegee. Daar word ook aangedui hoeveel organisasies die tegnieke toepas, asook die persentasie wat die syfers verteenwoordig ten opsigte van die totale aantal organisasies wat OO-tegnieke gebruik.

\section{$\underline{\text { TABEL } 1}$}

\section{OO-TEGNIEKE WAT IN DIE 73 ORGANISASIES GEBRUIK WORD}

\begin{tabular}{|l|c|c|}
\hline \multicolumn{1}{|c|}{ Tegnieke } & $\begin{array}{c}\text { Organisasies } \\
(\mathrm{N})\end{array}$ & $\begin{array}{c}\text { Persentasie van die } \\
73 \text { organisasies } \\
(\%)\end{array}$ \\
\hline Indienstegnieke & 66 & 90 \\
Strukturele veranderingstegnieke & 59 & 81 \\
Laboratoriumtegnieke & 53 & 73 \\
Doelwitbestuur & 51 & 70 \\
Taak en proses konsultasie & 39 & 53 \\
Ruitekaart- tipe opleiding & 33 & 45 \\
Opname gebaseerde tegnieke & 31 & 42 \\
Gedragmodifikasietegnieke & 21 & 29 \\
Beoordelingsentrums & 14 & 19 \\
Transaksionele analise & 12 & 16 \\
\hline
\end{tabular}

Uit Tabel 1 blyk dat die organisasies in die algemeen van 'n verskeidenheid tegnieke gebruik maak. Indienstegnieke - dit sluit tegnieke in soos werkrotasie, assistent aanstellings, 
tydelike taakmagte en spesiale opleidingsprojekte - word net in sewe van die organisasies nie toegepas nie. Die gewildheid van die tegnieke kan moontlik daaraan toegeskryf word dat die toepassing daarvan goedkoop is, nie die normale werkvloei onderbreek of versteur nie en ook nie 'n hoë vlak opleiding en ervaring van die persoon wat die tegnieke toepas, verg nie.

Strukturele veranderingstegnieke is tegnieke deur middel waarvan strukturele veranderinge in organisasies te weeg gebring word, byvoorbeeld in poste struktuur, hiërargie, werkinhoud, ensovoorts, en behels tegnieke soos werkherontwerp, veranderinge in personeelstelsels en in vergoedingstelsels. Werkverruiming en werkverryking is ook as strukturele veranderingstegnieke beskou. Die gebruik van die tegnieke in 59 organisasies, dui daarop dat die strukturele komponente van organisasies, wat dusver, volgens Levinson (1972) en Bowers (1976), so min aandag in OO-programme in die Verenigde State van Amerika geniet het, tog wel in van hierdie Suid-Afrikaanse ondernemings, saam met die ander organisasiekomponente in ag geneem word en doelwitte van veranderingspogings is.

Laboratoriumtegnieke soos T- of L-groepe, sensitiwiteitsopleiding, konfrontasiegroepe en spanbou word in $73 \%$ van die organisasies gebruik. OO-tegnieke soos die ruitekaart-tipe opleiding (dit sluit Blake en Mouton ruitekaart, LOS-seminare en aangepaste vorms daarvan in), gedragmodifikasietegnieke, beoordelingsentrums en transaksionele analise word veral in laboratoriumsituasies toegepas, en kan dus streng gesproke, ook as laboratoriumtegnieke beskou word. Die tipe tegnieke word ook in heelwat van die organisasies gebruik, soos in Tabel 1 aangedui.

Daar is aangetoon dat die teoretiese grondslag waarop laboratorium- en ruitekaart tegnieke berus, onder verdenking is en daar is daarop gewys dat die toepassing van laboratoriumtegnieke tot afnames in doeltreffendheidsmetings kan lei (Bowers 1973) en dat ander skrywers soos Levinson (1972), Bass (1967), Deep, Bass en Vaughan (1967) van mening is dat die tipe opleiding teenproduktief kan wees. Op grond hiervan blyk die wye toepassing van laboratoriumopleidingstegnieke in hierdie SuidAfrikaanse organisasies op 'n tendens wat bevraagteken moet word.

Die mees gesofistikeerde kategorie OO-tegnieke en ook die tegnieke wat volgens Bowers (1973) se studie die doeltreffendste is, naamlik opnameterugvoer-tegnieke word relatief min in die organisasies gebruik. Dit kan moontlik daaraan toegeskryf word dat die tegnieke nog nie so bekend is in Suid-Afrika as in ander lande nie en ook omdat die toepassing daarvan hoër eise stel aan die persone wat dit gebruik. 
Die samestelling van OO-progpamme

Gegewens oor die samestelling van OO-programme wat in die 73 organisasies toegepas word, word in Tabel 2 verstrek.

\section{$\underline{\text { TABEL } 2}$}

DIE SAMESTELLING VAN OO-PROGRAMME WAT IN DIE 73 ORGANISASIES GEBRUIK WORD

\begin{tabular}{|l|c|c|}
\hline \multicolumn{1}{|c|}{ Aard van OO-program } & $\begin{array}{c}\text { Organisasies } \\
(\mathrm{N})\end{array}$ & $\begin{array}{c}\text { Organisasies } \\
(\%)\end{array}$ \\
\hline 'n Pakket & 14 & 19 \\
Spesiaal vir die organisasie saamgestel & 48 & 66 \\
'n Spesifieke tegniek waaraan voorkeur & 12 & 16 \\
gegee word & 12 & 16 \\
Ander & 12 & 16 \\
\hline
\end{tabular}

Die bevinding dat twee derdes van die organisasies voorkeur gee aan tegnieke wat spesiaal vir die organisasie saamgestel is, laat die indruk dat OO-praktyk in Suid-Afrika in die algemeen gesond is. By verdere ontleding van die vraelys het dit geblyk dat 'n groot aantal vraelysvoltooiers tegnieke soos LOS-seminare as 'n spesiaal saamgestelde program vir hul organisasie beskou het, wat dit natuurlik nie is nie. Die geldigheid van die bevinding is dus onder verdenking.

Sou ons egter aanvaar dat die syfer korrek is, dan blyk dit dat 'n verdere 36 organisasies, óf van 'n 'pakket' gebruik maak ('n program wat vooraf saamgestel word en in dieselfde vorm aan organisasies bemark word, sonder om individuele organisasies se behoeftes in ag te neem) óf voorkeur gee aan die toepassing van 'n spesifieke tegniek.

'n OO-program behoort altyd aan te pas by die besondere omstandighede wat in 'n organisasie heers. In gevalle waar 'pakkette' sonder meer toegepas word, of waar 'n spesifieke tegniek net bloot toegepas word omdat geglo word dat die tegniek 'werk', word organisasie realiteite oor die hoof gesien. Daar is reeds daarop gewys dat die toepassing van OO-tegnieke altyd voorafgegaan moet word deur diagnose ten einde probleme te identifiseer. Daar kan met 'n redelike mate van sekerheid aanvaar word dat die diagnose nie vooraf onderneem word nie waar 'pakkette' of spesifieke 'voorkeur tegnieke' toegepas word. Daar is dus aanduidings dat heelwat organisasies bereid is om bepaalde tegnieke toe te pas sonder inagneming van hul spesifieke behoeftes. Tegniekgebondenheid blyk dus ook 'n kenmerk van OO-praktyk in 'n groot aantal van hierdie Suid-Afrikaanse organisasies te wees. 
Die beplanning en beheer van OO-programme

Wie is die mense wat die OO-programme in die 73 organisasies beplan en die beheer oor die verloop van die programme uitoefen? In Tabel 3 word die akademiese opleiding van die persone uiteengesit, terwyl daar in Tabel 4 'n ontleding gemaak word van hul ervaring met OO-werk.

\section{TABEL 3}

\section{DIE AKADEMIESE KWALIFIKASIES VAN PERSONE WAT OO-PROGRAMME BEPLAN EN BEHEER}

\begin{tabular}{|c|c|c|c|c|c|}
\hline \multirow{2}{*}{ Organisasies } & \multicolumn{4}{|c|}{ AKADEMIESE KWALIFIKASIE } \\
\cline { 2 - 6 } & $\begin{array}{c}\text { Nie } \\
\text { Universi- } \\
\text { teitsgraad } \\
\text { nie }\end{array}$ & $\begin{array}{c}\text { Baccalaureus } \\
\text { of } \\
\text { Honneurs } \\
\text { graad }\end{array}$ & $\begin{array}{c}\text { Meesters- } \\
\text { graad }\end{array}$ & $\begin{array}{c}\text { Doktors- } \\
\text { graad }\end{array}$ & $\begin{array}{c}\text { Geen } \\
\text { Inligting }\end{array}$ \\
\hline $\mathrm{N}$ & 18 & 16 & 18 & 8 & 13 \\
$\%$ & 25 & 22 & 25 & 11 & 17 \\
\hline
\end{tabular}

\section{TABEL 4}

\section{ERVARINGS MET OO-WERK VAN PERSONE WAT OO-PROGRAMME BEPLAN EN BEHEER}

\begin{tabular}{|c|c|c|c|c|}
\hline \multirow{2}{*}{ Organisasies } & \multicolumn{4}{|c|}{ JARE ERVARING } \\
\cline { 2 - 5 } & 5 en minder & $6-9$ & 10 en meer & Geen inligting \\
\hline $\mathrm{N}$ & 17 & 14 & 18 & 24 \\
$\%$ & 23 & 19 & 25 & 33 \\
\hline
\end{tabular}

Die gegewens in Tabel 3 verstrek, dui aan dat slegs 36\% van die persone wat OOprogramme beplan en beheer, oor 'n gevorderde akademiese kwalifikasie ('n meesters- of doktorsgraad) beskik. In $25 \%$ van die organisasies het die persoon nie oor 'n universiteitsgraad beskik nie en 13 organisasies (17\%) wou of kon nie inligting verstrek oor die akademiese opleiding van die persone nie. Uit Tabel 4 blyk dit dat dieselfde tendens voorkom met betrekking tot die ervaring van die persone, $23 \%$ het slegs 5 of minder jare ervaring, terwyl een derde van die organisasies nie inligting wou of kon verstrek oor die ervaring van die persone nie.

In die bespreking van die tekortkominge van OO-tegnieke is verwys na Levinson (1972) se opmerking dat die meeste mense wat OO-tegnieke toepas, nie oor genoegsame 
opleiding vir die taak beskik nie. Die gegewens, hierbo uiteengesit, dui daarop dat die opmerking ook waarskynlik waar kan wees ten opsigte van sommige persone wat die toepassing van OO-tegnieke in die 73 organisasies beplan en beheer.

In 35 organisasies (48\%) word van die dienste van buite konsultante gebruik gemaak, terwyl 33 (45 \%) uitsluitlik hul eie personeel gebruik. In 29 organisasies (39\%) is konsultante, afkomstig uit Europa of die Verenigde State van Amerika, gebruik, terwyl slegs 8 organisasies (11\%) Suid-Afrikaanse buite konsultante se dienste gekoop het. Van die 35 organisasies wat buite konsultante gebruik het, het 26 die buite konsultante om hul dienste gevra; terwyl 9 organisasies deur die buite konsultante genader is wat hulle dienste aan die organisasies kom aanbied het.

\section{Die gebruik van diagnose in OO-programme}

Daar is telkens beklemtoon dat ' $\mathrm{n}$ deeglike diagnose van probleme en behoeftes ' $n$ voorvereiste is vir beplande en sistematiese organisasie-ontwikkeling. Gegewens in verband met die gebruik van diagnose in OO-programme word in Tabel 5 verstrek.

\section{TABEL 5}

DIE MAAK VAN DIAGNOSE EN DIE GEBRUIKMAKING VAN DIE INLIGTING IN OO-PROGRAMME

\begin{tabular}{|c|c|c|c|}
\hline \multirow{2}{*}{ Organisasies } & \multicolumn{3}{|c|}{ DIAGNOSE } \\
\cline { 2 - 4 } & Deurgaans & Soms & Glad nie \\
\hline $\mathrm{N}$ & 46 & 15 & 12 \\
$\%$ & 63 & 20 & 17 \\
\hline
\end{tabular}

Ses en veertig organisasies $(63 \%)$ rapporteer dat hulle diagnose onderneem en die diagnose gebruik as basis vir OO-program beplanning. In 15 organisasies word die diagnose soms gemaak en soms gebruik vir beplanning. In die oorblywende 12 organisasies (17\%) word geen diagnose gemaak nie. Bykans twee derdes van die organisasies blyk dus 'n wetenskaplike benadering te volg tot die instelling en gebruik van OO-programme. Die vraag ontstaan egter, of die manier waarvolgens die diagnose gemaak word, wel as wetenskaplik beskou kan word. Inligting oor hoe die diagnoses gemaak word verskyn in Tabel 6.

Vraelyste na werknemerhoudings word in 23 organisasies (32\%) toegepas - in 6 organisasies ( $8 \%$ ) op sigself en in 17 ander in kombinasie met ander metodes. Die nagaan van beskikbare rekords (onder meer produksiestate), beoordelings van werknemerprestasie en 
bestuur se siening van ontwikkelingsbehoeftes is ook metodes wat gebruik word om OObehoeftes uit te wys. Die gegewens in Tabel 7 dui aan dat in die diagnoses veral gelet word op die individuele substelsel van organisasies ten einde behoeftes en probleme te diagnoseer en dat die ander substelsels van die organisasie, bv. die organisasie-, taak en sosiale struktuur, dikwels oor die hoof gesien word. Die gegewens dui ook daarop dat die wisselwerking tussen die verskillende substelsels nie dikwels in die diagnose fase ondersoek word nie.

\section{TABEL 6}

\section{METODES WAARVOLGENS DIAGNOSE VAN OO-BEHOEFTES GEMAAK WORD}

\begin{tabular}{|ll|c|c|}
\hline \multirow{2}{*}{ Diagnose deur - } & \multicolumn{2}{c|}{ Organisasies } \\
\cline { 3 - 4 } 1. & Die nagaan van beskikbare rekords & $\mathrm{N}$ & $\%$ \\
\hline 2. & Beoordelings van werknemerprestasie & 8 & 12 \\
3. & Bestuur se siening van ontwikkelingsbehoeftes in te win & 7 & 12 \\
4. & Vraelyste na werknemerhoudings & 6 & 8 \\
5. & Ander vraelyste & 4 & 5 \\
6. & Ander metodes (byvoorbeeld kritiese insidente, & 7 & 10 \\
7. & ondervraging van werknemers) & & 12 \\
8. & Beide 4 en 1 4 en 2 & 1 & 16 \\
9. & Beide 4 en 3 & 3 & 4 \\
10. & Beide 4 en 5 & 1 & 1 \\
11. & Doen nie diagnose nie & 12 & 16 \\
\hline
\end{tabular}

Gesien die belangrikheid van die diagnose fase in enige organisasieontwikkelingsprogram behoort organisasies heelwat meer aandag te skenk aan die sistematiese identifisering van organisasie-ontwikkelingsbehoeftes. Nie net die individuele substelsel nie, maar alle organisasie substelsels en die wisselwerking tussen hulle, moet ondersoek word. Die inligting moet gebruik word om die verdere verloop van die OO-program te beplan.

\section{Die evaluering van OO-programme}

In Tabel 7 word aangetoon dat meer as die helfte van die 73 organisasies hul OOprogramme, na die afloop daarvan, evalueer. 
$\underline{\text { TABEL } 7}$

\section{DIE EVALUERING VAN OO-PROGRAMME}

\begin{tabular}{|l|l|r|}
\hline \multirow{2}{*}{ OO-Programme } & \multicolumn{2}{|c|}{ Organisasies } \\
\cline { 2 - 3 } & $\mathrm{N}$ & $\%$ \\
\hline Word geëvalueer & 40 & 55 \\
Word soms geëvalueer & 22 & 30 \\
Geen inligting verstrek nie & 11 & 15 \\
\hline
\end{tabular}

Die gegewens wek die indruk dat OO-praktisyns in Suid-Afrika nie so 'n groot weerstand teen die evaluering van OO-programme toon nie, as wat Tichy (1974) en Brown en Somerville (1977) in die Verenigde State van Amerika teëgekom het.

Net soos in die geval van diagnose is die belangrike vraag egter hoe die evaluering gedoen word, dit wil sê, watter kriteria gebruik word om die doeltreffendheid van die OOprogramme te evalueer. Inligting hieroor verskyn in Tabel 8.

Slegs drie organisasies (4\%) maak in die evaluering van OO-programme uitsluitlik van eksterne kriteria gebruik. Die beswaar, dat OO-programme baie selde teen slegs eksterne, die sogenaamde harde kriteriadata, soos verbeterde produksie, groter doeltreffendheid, verminderde afwesigheid en arbeidsomset geëvalueer word, geld dus ook vir meeste van hierdie Suid-Afrikaanse organisasies.

Die interne kriteria wat in 42 organisasies $(58 \%)$ gebruik is om die doeltreffendheid

\section{TABEL 8}

\section{DOELTREFFENDHEIDSKRITERIA GEBRUIK IN EVALUERING VAN OO-PROGRAMME}

\begin{tabular}{|l|c|c|}
\hline \multirow{2}{*}{ Doeltreffendheidskriteria } & \multicolumn{2}{|c|}{ Organisasies } \\
\cline { 2 - 3 } & $\mathrm{N}$ & $\%$ \\
\hline Slegs eksterne kriteriadata & 3 & 4 \\
Slegs interne kriteriadata & 42 & 58 \\
Beide eksterne en interne data & 14 & 19 \\
Geen inligting verstrek nie & 14 & 19 \\
\hline
\end{tabular}

van hul OO-programme te bepaal, is veral houdingsveranderinge wat individue ondergaan, persone wat OO-programme deurloop se eie subjektiewe verslae oor die doeltreffendheid van programme, sowel as OO-praktisyns se menings oor die geslaagdheid daarvan. As die 
aanname gemaak word dat 'n OO-program wel effektief is op grond van slegs sodanige beoordelings, kan die wetenskaplikheid van evaluasie in twyfel getrek word.

\section{Geld en man-ure aan OO-programme bestee}

In die ondersoek is organisasies gevra om aan te dui hoeveel geld en man-ure gedurende die twee jaar, wat die ontvangs van die vraelys voorafgegaan het, aan OOprogramme bestee is. Slegs 52 organisasies was bereid om inligting hieroor te verstrek. In hierdie 52 organisasies is gesamentlik R2 518700 gedurende die twee jaar tydperk aan OOprogramme bestee - dit verteenwoordig 'n gemiddeld van meer as R24 000 per organisasie per jaar.

In Tabel 9 word inligting aangaande die verspreiding van bestedings weergegee.

\section{$\underline{\text { TABEL } 9}$}

FONDSE AAN OO-PROGRAMME BESTEE

\begin{tabular}{|l|c|c|}
\hline \multirow{2}{*}{ Doeltreffendheidskriteria } & \multicolumn{2}{|c|}{ Organisasies } \\
\cline { 2 - 3 } & $\mathrm{N}$ & $\%$ \\
\hline Minder as 1000 & 2 & 3 \\
$1000-9000$ & 12 & 16 \\
$10000-24000$ & 9 & 12 \\
$25000-49000$ & 10 & 14 \\
$50000-99000$ & 9 & 12 \\
$100000-149000$ & 6 & 8 \\
$150000-199000$ & 2 & 3 \\
200000 en meer & 2 & 3 \\
Geen inligting verstrek nie & 21 & 29 \\
\hline
\end{tabular}

Veertig van die 73 organisasies was bereid om inligting bekend te maak oor die totale aantal man-ure aan OO-opleiding bestee oor die bogenoemde twee jaar periode. Gedurende die tydperk is altesaam 324700 man-ure in hierdie organisasies aan OO-opleiding bestee, ' $\mathrm{n}$ gemiddeld van 4 058,75 uur per organisasie per jaar of 507,2 agtuur-werksdae per organisasie per jaar. Die ware aantal man-ure bestee is na alle waarskynlikheid baie meer, aangesien die vraag in die vraelys wat oor hierdie aspek gehandel het moontlik verwarrend was. In baie gevalle is slegs die man-ure vermeld wat deur persone in beheer van OO- programme bestee is en is die man-ure bestee deur werknemers aan die deurloping van OO- opleiding nie bygereken nie. 
Uit hierdie gegewens is dit egter duidelik dat OO-opleiding in hierdie Suid-Afrikaanse organisasies duur is in terme van geld en man-ure daaraan bestee.

\section{Die doeltreffendheid van OO-programme}

Weens die vraagstukke rakende die doeltreffendheid van OO-programme, soos reeds verduidelik is, was een van die doelwitte van hierdie opname om te probeer bepaal hoe doeltreffend die OO-programme is wat in die organisasies toegepas word. Omdat dit onmoontlik is om die doeltreffendheid van hierdie programme op 'n objektiewe wyse tydens 'n opname soos hierdie te bepaal, is besluit om as 'n uitweg die voltooier van die vraelys te versoek om eerstens sy eie siening oor die doeltreffendheid van programme in sy organisasie toegepas, op 'n vierpunt skaal, wat strek van uiters effektief na effektief, weer te gee. Inligting oor hierdie beoordeling verskyn in Tabel 10.

\section{TABEL 10}

\section{VRAELYS-VOLTOOIERS SE BEOORDELING VAN DIE DOELTREFFENDHEID VAN OO-PROGRAMME IN HUL ORGANISASIES}

\begin{tabular}{|l|c|c|}
\hline \multirow{2}{*}{ OO-Program beoordeel as } & \multicolumn{2}{|c|}{ Organisasies } \\
\cline { 2 - 3 } & $\mathrm{N}$ & $\%$ \\
\hline Uiters doeltreffend & 4 & 5 \\
Doeltreffend & 33 & 45 \\
Soms doeltreffend & 16 & 22 \\
Ondoeltreffend & 0 & 0 \\
Inligting nie verstrek nie & 20 & 28 \\
\hline
\end{tabular}

In 'n verdere vraag is die voltooiers versoek om aan te dui wat die algemene beskouing in hul organisasie is oor die doeltreffendheid van OO-programme wat in hul organisasies uitgevoer is. Die inligting hieroor word in tabel 11 opgesom. 
$\underline{\text { TABEL } 11}$

\section{DIE ALGEMENE BESKOUING IN ORGANISASIES OOR DIE DOELTREFFENDHEID VAN OO-PROGRAMME}

\begin{tabular}{|l|c|c|}
\hline \multirow{2}{*}{ OO-Programme word in die algemeen beskou as } & \multicolumn{2}{|c|}{ Organisasies } \\
\cline { 2 - 3 } & $\mathrm{N}$ & $\%$ \\
\hline Uiters doeltreffend & 1 & 1 \\
Doeltreffend & 19 & 26 \\
Soms doeltreffend & 38 & 52 \\
Ondoeltreffend & 3 & 4 \\
Inligting nie verstrek nie & 12 & 17 \\
\hline
\end{tabular}

In teenstelling met Tabel 10, wat aantoon dat die helfte van die vraelys voltooiers die OO-programme in hul organisasies toegepas as doeltreffend of uiters doeltreffend beskou, dui hierdie mense aan (Tabel 11) dat hulle die algemene siening, ten opsigte hiervan in hulle organisasies, as baie minder gunstig waarneem. In die meerderheid gevalle word aangedui dat die mees algemene beskouing is dat OO-programme net soms doeltreffend is.

Die gegewens weergegee in Tabelle 10 en 11 dui op die moontlikheid dat daar heelwat meningsverskille bestaan oor die doeltreffendheid van OO-programme. Dit kan waarskynlik in 'n groot mate toegeskryf word aan die gebrekkige evaluering van OO-programme soos hierbo bespreek is. Daar moet egter in gedagte gehou word dat die doeltreffendheidsbeoordelings in Tabelle 10 en 11 weergegee, bloot subjektiewe menings is.

Desnieteenstaande die waarskynlike onsekerheid oor die doeltreffendheid van OOtegnieke, dui 55 organisasies ( $75 \%$ ) aan dat hulle definitief in die toekoms weer OO-tegnieke gaan toepas, 8 organisasies $(10 \%)$ dui aan dat hulle dit moontlik weer gaan toepas, terwyl die res nie hieroor inligting wou of kon verstrek nie.

Daar is dus aanduidings dat daar ook in minstens sommige van hierdie organisasies onsekerheid bestaan oor die doeltreffendheid van OO-tegnieke. As dit nou gesien word teen die agtergrond van uitsprake van skrywers, soos Beer (1976), Bowers (1976) Kahn (1974), Tichy (1974) en Levinson (1972), dat daar min bewyse bestaan dat die toepassing van OOtegnieke lei tot die verhoging van individuele- en organisasiedoeltreffendheid, dat die uitwerking en gevolge wat OO-tegnieke het, nog in 'n groot mate onbekend is en as daar verder in ag geneem word dat organisasies heelwat geld en man-ure in die tipe opleiding belê, toon dit die noodsaaklikheid daarvan dat organisasies deurgaans behoort te poog om die doeltreffendheid van OO-programme te evalueer. 


\section{GEVOLGTREKKINGS}

Die belangrikste bevindings van die ondersoek is die volgende:

'n Verskeidenheid OO-tegnieke word in meeste van die organisasies toegepas en groot bedrae geld, 'n gemiddeld van meer as R24 000 per organisasie per jaar, word hieraan bestee.

Daar is aanduidings dat van die organisasies wetenskaplik te werk gaan in die gebruik van OO-tegnieke deurdat hulle vooraf - op 'n wetenskaplike wyse - poog om 'n ontleding of diagnose te maak van behoeftes en probleme in al die substelsels van die organisasie. OOtegnieke word dan deur deskundiges met genoegsame opleiding en ervaring, toegepas.

Hierdie OO-tegnieke is tegnieke wat gerig is op die oplossing van die spesifieke geïdentifiseerde probleme. Na toepassing van die tegnieke word die doeltreffendheid van OOopleiding geëvalueer.

Aan die ander kant blyk dit dat alhoewel van die organisasies rapporteer dat diagnoses van behoeftes en probleme vooraf gemaak word, die gegewens daarop dui dat die diagnose in baie van die gevalle op 'n onwetenskaplike, lukraak manier gedoen word. Meer as 'n derde van die organisasies pas OO-tegnieke toe wat deel uitmaak van 'n pakket of waaraan hulle spesifieke voorkeur gee. Deur dit te doen word aanvaar dat die OO-tegnieke relevant is tot die organisasie se spesifieke probleme en dat dit die probleme sal verbeter. Navorsing dui daarop dat bogenoemde aannames op onvaste gronde staan.

Daar word ook in die organisasies tegnieke toegepas waarvan die wetenskaplike basis onder verdenking is en waarvan min bekend is oor die doeltreffendheid en uitwerking van die tegnieke. Die toepassing van tegnieke is dikwels gerig op die verandering van slegs 'n bepaalde organisasie substelsel.

Organisasies kon of wou in heelwat gevalle nie rekenskap gee van die opleiding en ervaring van konsultante wat in hul organisasies die toepassing van OO-tegnieke beplan en beheer nie. Daar is ook aanduidings dat die tegnieke in organisasies toegepas word deur persone wat nie oor die nodige opleiding en ervaring beskik nie.

Die doeltreffendheid van OO-tegniek-toepassing word in slegs $3 \%$ van die organisasies op 'n wetenskaplike wyse geëvalueer. Die gevolgtrekking kan dus gemaak word dat daar baie min bekend is oor die doeltreffendheid, gevolge en uitwerking, wat die toepassing van die tegnieke het. Die toedrag van sake kan niks bydra om lig te werp op die bestaande meningsverskille oor die doeltreffendheid van OO-tegnieke nie. 
Alhoewel daar dus aanduidings bestaan dat OO-tegnieke in heelwat van die organisasies op 'n wetenskaplike manier beplan, toegepas en geëvalueer word, dui die bevindings daarop dat die kritiek wat navorsers oor die toepassing en doeltreffendheid van OO-tegnieke uitgespreek het ook waar kan wees ten opsigte van die gebruik van die tegnieke in heelwat van hierdie groot Suid-Afrikaanse organisasies.

Daar bestaan bedenkinge oor veral die wyse waarop organisasieontwikkelingsbehoeftes geïdentifiseer word; oor die mate waarin geïdentifiseerde behoeftes as basis vir die beplanning van OO-programme gebruik word; oor die verskynsel dat min pogings aangewend word om die doeltreffendheid van OO-programme te evalueer; oor of die persone wat OO-programme beplan en beheer deurgaans oor die laboratorium-tipe tegnieke, tegnieke wat in pakketvorm bemark word en spesifieke tegnieke waaraan organisasies voorkeur gee, ongeag die besondere probleme en behoeftes van die bepaalde organisasie. Pogings waar die totale organisasie en nie net afsonderlike substelsels nie, betrek word, behoort ook meer aandag te geniet.

Die Bedryfsielkundige het 'n belangrike taak en bydrae te lewer ten einde hierdie tekortkominge in die toepassing van organisasie-ontwikkelingstegnieke in Suid-Afrika te bowe te kom, veral ten opsigte van die uitbouing van die teoretiese basis waarop die tegniektoepassing berus, die ontwikkeling van tegnieke om probleemgebiede en opleidingsbehoeftes te identifiseer en om metodes te ontwikkel waarvolgens die doeltreffendheid van ingrypings in organisasies geëvalueer kan word. Aan die ander kant moet die betrokke bestuurders in organisasies bewus gemaak word van die bestaande probleemareas en moet hulle aangemoedig word om groter omsigtigheid aan die dag te lê met betrekking tot al die aspekte rakende die toepassing van OO-tegnieke wat hier bespreek is.

\section{OPSOMMING}

Inligting oor verskeie aspekte van organisasieontwikkelingstegnieke soos toegepas in 73 groot Suid-Afrikaanse organisasies dui daarop dat dit soms wetenskaplik goed gefundeer is. By andere egter kom heelwat leemtes voor. Die spesifieke probleme en moontlike oorsake daarvan word bespreek en aanbevelings ter verbetering van organisasie-ontwikkelingspraktyk word aan die hand gedoen. 


\section{VERWYSINGS}

Argyris, C. Management and Organizational Development: The Path from Xa to Xb. New York: McGraw-Hill, 1971.

Bass, B.M. The anarchist movement and the T-group. Journal of Applied Behavioral Science, 1967, 3, 211-226.

Beckhard, R. Organizational Development: Strategies and Models. Reading, Mass.: AddisonWesley, 1969.

Beer, M. The technology of organization development. In Dunnette, M.D. (Red.), Handbook of Industrial and Organisational Psychology. Chicago: Rand McNally, 1976.

Bowers, D.G. OD techniques and their results in 23 organizations: the Michigan ICL study. Journal of Applied Behavioral Science, 1973, 9(1), 21-42.

Bowers, D.G. Organization development: it's promises, performance and possibilities. Prepublication Draft, 1976.

Brown, R.J. \& Somerville, J.D. Evaluation of management development programs: an innovative approach. Personnel, 1977, 54(4), 28-39.

Deep, S., Bass, B.M. \& Vaughan, J. Some effects on business gaming of previous quasi-Tgroup applications. Journal of Applied Psychology, 1967, 51, 426-431.

Frank, F. Questions and answers on organizational development. Industrial Training International, 1976, 11(9), 2.

Franklin, J.R. Organization Development: an Annotated Bibliography. ISR, The University of Michigan. Ann Arbor, Michigan, 1973.

Friedlander, F. \& Brown, D.L. Organization development. Annual Review of Psychology, 1975, 25, 313-341.

Huse, E.F. Organizational Development and Change. St. Paul: West Publishing Co., 1975.

Kahn, R.L. Organization development: some problems and proposals. Journal of Applied Behavioral Science. 1974, 10(4), 485-502.

Levinson, $\mathrm{H}$. The clinical psychologist as organizational diagnostician. Professional Psychology, 1972, 3, 34-40.

Tichy, N. An interview with Max Pages. Journal of Applied Behavioral Science, 1974, 10(1), 8-26.

Top Companies. Financial Mail Special Survey, April 22, 1977. 